\title{
Introduction of Heterocycles at the 2-Position of Indoline as Ester Bioisosteres
}

\author{
Sunkyung Lee, Kyu Yang $Y i,{ }^{\text {, }}$ and Sung-eun Yoo \\ Medicinal Science Division. Korea Research Insihnte of Chemical Technology. \\ P.O. Box 107, Yoosung-gu, Daejeon 305-600, Korea \\ Received November 25, 2003
}

\begin{abstract}
In this study, we attempted to prepare compounds with heterocyclic replacements for metabolically unstable esters of benzopyranyl indole-2-carboxylic esters, which showed good in vitro and in vivo cardioprotective efficacies possibly through the opening of mitochondrial ATP-sensitive potassium channel $\left(K_{+} \mid \mathrm{P}\right)$. Initially, we tried to construct indolin-2-yl-heterocycles using unprotected indoline-2-carboxylic acid, but the cyclization was proceeded with oxidation of the indoline ring to the indole, which didn t react with benzopyranyl epoxide. Thus we introduced $N$-Boc group to deplete the electron density of the indoline ring. We successfully prepared various indolin-2-yl-heterocycles by the cyclization of the building blocks including carboxam ide, $\beta$-hydroxy anide, hydrazide, nitrile starting from $N$-Boc-indoline-2-carboxylic acid.
\end{abstract}

Key Words : $N$-Boc protection. Ester bioisostere, Indolin-2-yl-heterocycles

\section{Introduction}

In previous study, we found that benzopyranyl indole-2carbocylic ester analogs showed good in viro and in vivo cardioprotective efficacies possibly through the opening of mitochondrial ATP-sensitive potassium channel $\left(K_{\mathrm{ATP}}\right)$. $^{\prime}$ Regardless the good efficacies of the compounds, we were concerned on the susceptibility of the ester group to metabolic cleavage. Then, as a starting point in the design, the hydrolytically stable bioisosteres of the ester functionality in benzopyranyl indoles were considered. In this paper we describe the synthesis of various indolin-2-yl-heterocycles, bioisosterically replaced for ester group including oxazole, oxadiazole, and tetrazole.

\section{Results and Discussion}

As shown in Scheme 1, previously we prepared benzopyranyl indoline-2-carboxilic ester analogs from optically pure benzopyranyl epoxides with the indolines by epoxide opening in the presence of magnesium perchlorate in $\mathrm{CH}_{3} \mathrm{CN} .{ }^{2}$ The same reaction with an indole didn't give any

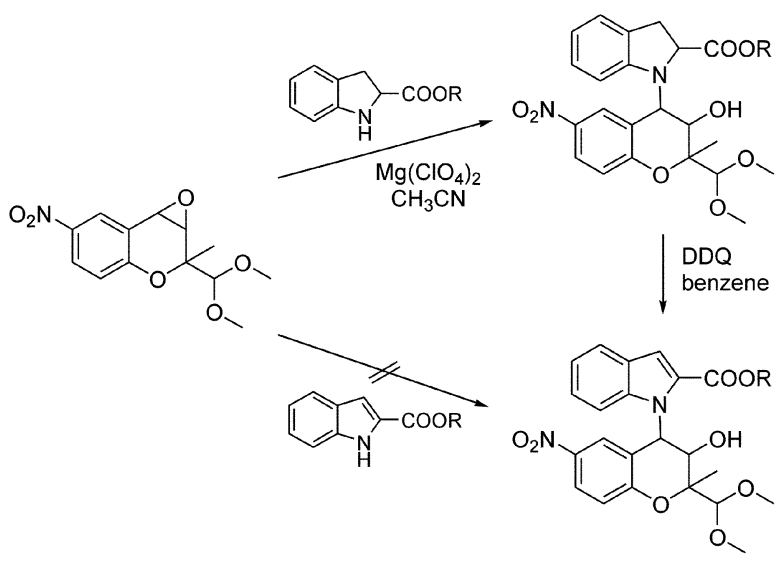

Scheme 1

reasonable yield of products under various conditions, but the oxidation of benzopyranyl indolines with 2.3-dichloro5,6-dicyano-1,4-benzoquinone (DDQ) provided desired benzopyranyl indoles in good yields.'

Primarily, we attempted to prepare indoline compounds with heterocyclic replacements for esters by construction of
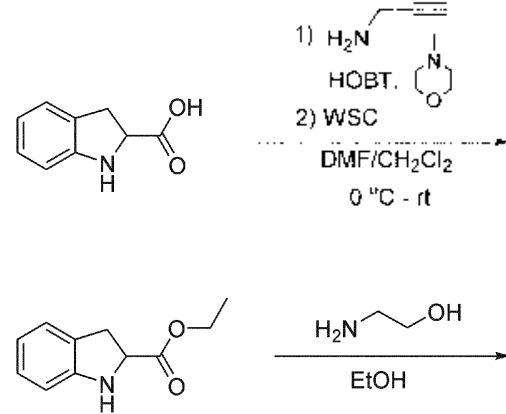<smiles>C#CCNC(=O)C1Cc2ccccc2N1</smiles>

1
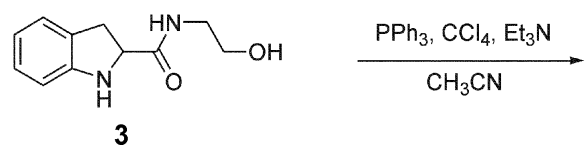

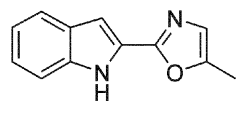

2

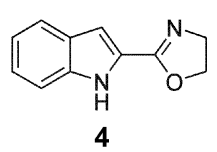

Scheme 2

"To whon correspondence should be addressed: Tel: +82-42-860-7143; Fax: +82-42-861-129]; c-mail; kyyi@krict.re.kr 


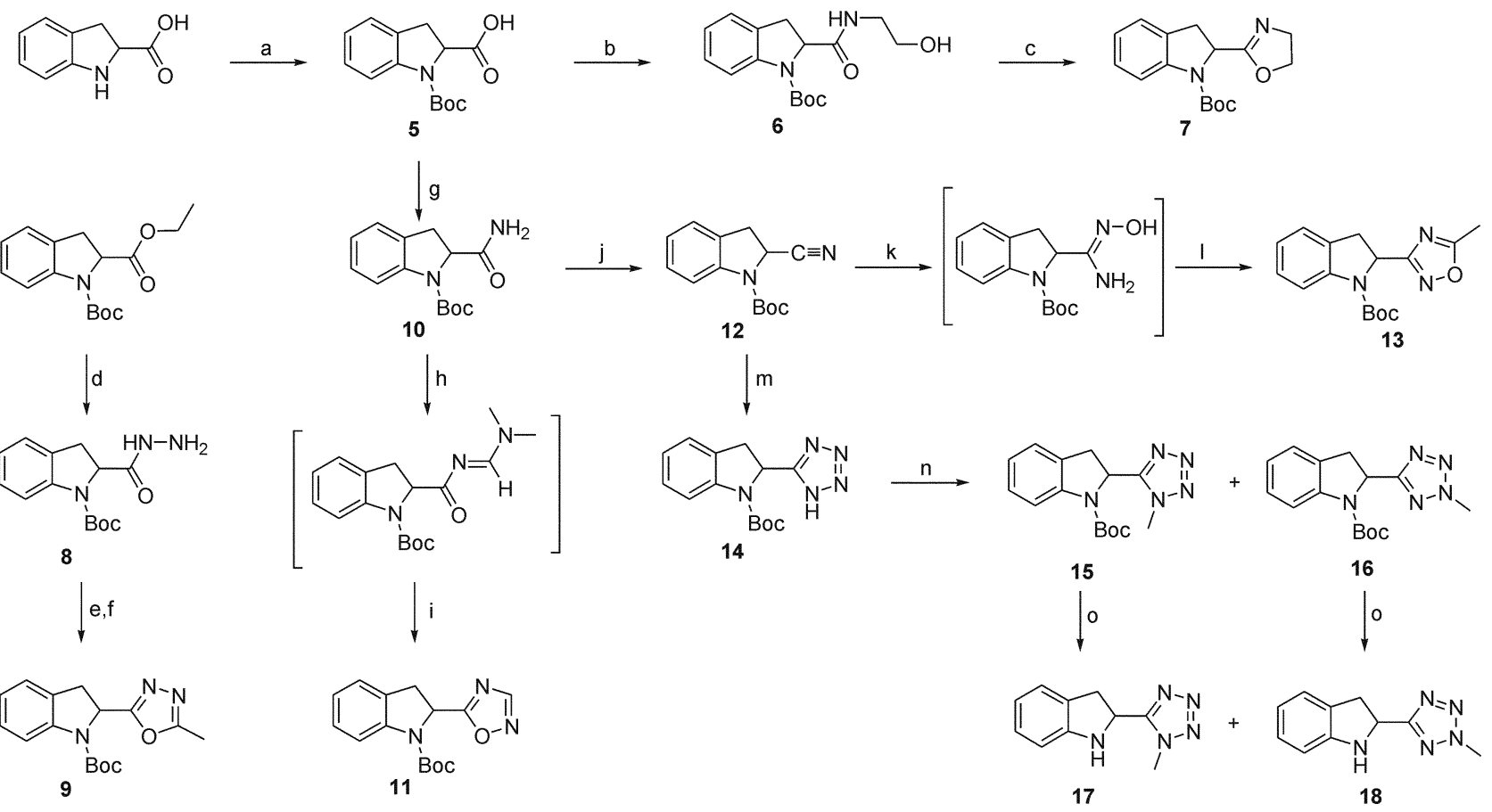

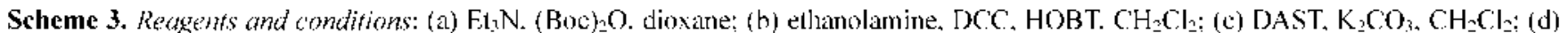

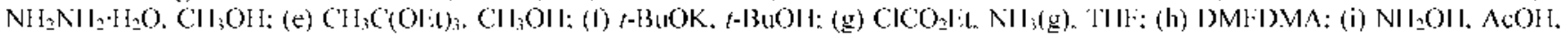

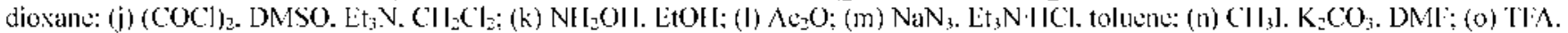
$\mathrm{CH}_{2} \mathrm{Cl} \cdot$.

the ring from indoline-2-carboxylic acid (Scheme 2). The acid was smoothly coupled with propargylamine using water soluble carbodimide (WSC) to give the amide 1 , and following treatment of 1 with $\mathrm{Hg}(\mathrm{OAc})_{2}$ in acetic acid gave the cyclized oxazole $2^{3}$ with an additional oxidation of the indoline ring to the indole. The 2-hydroxyethylamide 3 was cyclized to oxazoline through the amide- $O$-triphenylphosphonium salt in the presence of triphenylphosphine $\mathrm{CCl}_{4}{ }^{\prime}$, which oxidaized the indoline to the indole, too. The indoline seemed to readily oxidize to the indole, presumably due to the high electron density. ${ }^{5}$ Thus we decided to deplete the electron density by $\mathrm{N}$-Boc protection.

We prepared indolin-2-yl-heterocycles by the cyclization of the building blocks including $\beta$-hydroxy amide 6 , hydrazide 8 , carboxamide 10 , and nitrile 12 , starting from $N$ Boc-indoline-2-carboxylic acid 5 (Scheme 3).

$\mathrm{N}$-Boc-protected compound $\mathbf{5}$ was readily obtained from indoline-2-carboxylic acid using di-t-butylcarbonate in the presence of triethylamine in $94 \%$ yield. The acid 5 was converted to $\beta$-hydroxy amide 6, which was cyclized to oxazoline 7 with diethylaminosulfur trifluoride (DASI). ${ }^{6}$ The dehydrative ring-closure using DASI gave the higher yield $(91 \%)$ than Mitsunobu condition (62\%).

Synthesis of 5-methyl-1,3,4-oxadiazole 9 was achieved by treatinent of ester with hydrazine followed by cyclization with triethyl orthoacetate. ${ }^{7}$ The reaction of carboxamide $\mathbf{1 0}$ with $N, N$-dimethylformamide dimethylacetal (DMFDMA) and subsequent cyclization of the intermediate amidine with hydroxylamine afforded 1,2,4-oxadiazole 11. ${ }^{\$}$-Methyl1,2,4-oxadiazole 13 was obtained in similar method through
N-hydroxy amidine precursor from nitrile 12 , The required nitrile 12 was prepared by dehydration of carboxamide $\mathbf{1 0}$. We employed the Swern oxidation conditions ${ }^{10}$ for this transformation using the "activated" dimethyl sulfoxide species, because of acid-sensitive $N$-Boc group. ${ }^{11}$ lt has been reported that both acid-sensitive (epoxide, acetonide, silyl, $\mathrm{N}$-Boc, $\mathrm{N}$-Cbz) and alkaline-sensitive groups (Ac, B7, ester, silyl) were completely unaffected under this mild conditions. 1?

The tetrazole 14 was obtained from the nitrile 12 using the classical triethylamine hydrochloride/sodium azide procedure in excellent yield $(91 \%){ }^{1.3}$ The $N$-methylation of tetrazole gave the regioisomeric I-methyl (15, 46\%), and 2-Inethyltetrazole $(16,51 \%)$, which were assigned by ' $\mathrm{H}$ nmr specta. The $N$-methyl peak of 1 -methytetrazole 15 was very broad presumably due to the restriction of rotation by $N$-Boc group, while that of 2-methyltetrazole 16 was very sharp. $N$ Boc group of both tetrazoles (15, 16) were deprotected under acidic condition ( $\mathrm{TFA}: \mathrm{CH}_{2} \mathrm{Cl}_{2}=1: 1$ ). Resulting racemic terazole indoline compounds $(\mathbf{1 7}, \mathbf{1 8})$ were smoothly reacted with optically pure $(2 S, 3 R, 4 R)$ epoxide in the presence of magnesium perchlorate to yield the benzopyranyl indolines $(\mathbf{1 9 - 2 2})$ as shown in Scheme $4{ }^{14}$ The reactions provided two separable diastereoisomers at indoline-2-position, respectively, of which absolute stereochemistry was confirmed by the synthesis of authentic compound using commercially available (-)-(S)-indoline-2-carboxylic acid as a starting material. The indole compound 23 was prepared by oxidation of the corresponding indoline $(21,22)$ with $\mathrm{DDQ}$ in good yield $(91 \%)$.

With the benzopyranyl indol-2-yl-heterocycles in hand, 


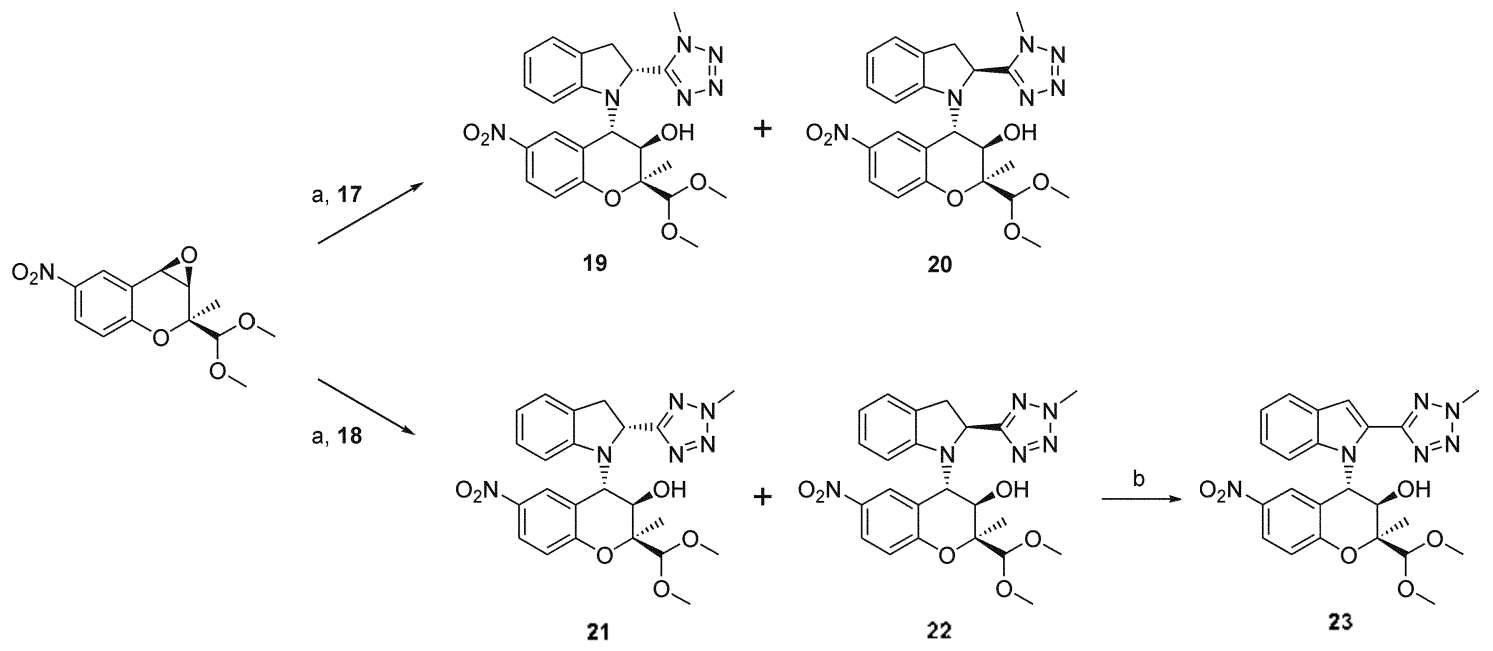

Scheme 4. Reagents and conditiont: (a) $\mathrm{Mg}\left(\mathrm{C} / \mathrm{O}_{4}\right.$ ). $\mathrm{CII}_{3} \mathrm{CN}$ : (b) DDQ. benzenc.

we will continuously study the anti-ischemic effects of these compounds to expect the increased metabolic stabilities as well as efficacies.

\section{Conclusion}

We prepared various indolin-2-yl-heterocycles, bioisosterically replaced for ester group by the construction of the beterocyclic ring starting from $N$-Boc-indoline-2-carboxylic acid to avoid oxidation of the indoline ring to the indole by the depletion of electron density of the indoline ring.

\section{Experimental Section}

Chemistry. Anhydrous solvents were dried by conventional methods. Reagents of commercial quality were used from freshly opened containers unless otherwise stated. For purification of products by column chromatography. Merck silica gel 60 (230-400 mesh) was used. 'H NMR spectra were recorded on a Varian Gemini 200 with 'lMS as an internal standard. Chemical shifts are reported in $\delta$ (ppm). Mass spectra were obtained with a JEOL JMS-DX 303 instrument by using electro impact techniques.

Indoline-2-( $N$-propargyl)carboxamide ( 1$)$. To a solution of indoline-2-carboxylic acid (500 mg. $3.1 \mathrm{mmol}$ ), Ihydroxybenzotriazole (430 $\mathrm{mg}, 3.1 \mathrm{mmol}$ ), $N$-methylmorpholine $(0.6 \mathrm{~mL}, 5.1 \mathrm{mmol})$, and propargylamine $(0.2 \mathrm{~mL}$, $3.0 \mathrm{mmol}$ ) in $\mathrm{CH}_{2} \mathrm{Cl}_{2}$-DMF ( $1: 1,40 \mathrm{~mL}$ ) was added 1-[3(dimethylamino)propyl]-3-ethylcarbodiimide hydrochloride (300 $\mathrm{mg}, 3.1 \mathrm{mmol}$ ) at $0{ }^{\circ} \mathrm{C}$. The solution was stirred overnight at room temperature and washed with water, and the aqueous layer was separated and extracted with $\mathrm{CH}_{2} \mathrm{Cl}_{2}$. The combined organic layers were dried over $\mathrm{Na}_{2} \mathrm{SO}_{4}$, filtered, and concentrated under reduced pressure. The residue was purified by silica gel column chromatography $\left(5 \%\right.$ methanol in $\left.\mathrm{CH}_{2} \mathrm{Cl}_{2}\right)$ to yield the propargylamide $\mathrm{I}(220$ mg. $36 \%):{ }^{1} \mathrm{H}$ NMR (200 MHz, CDCl 3 ): $\delta 2.22$ (m, IH). 3.09 (dd, $1 \mathrm{H}, J=8.6,16.5 \mathrm{~Hz}$ ), 3.60 (dd, $1 \mathrm{H}, J=10.8,16.5$ $\mathrm{Hz}), 4.09(\mathrm{~m}, 2 \mathrm{H}), 4.45(\mathrm{dd}, 1 \mathrm{H}, J=8.8,10.7 \mathrm{~Hz}), 6.74-6.87$ (m, 2H), 7.05-7.13 (m, 2H), 7.31 (brs, 1H).

2-(5-Methyl-1,3-oxazol-2-yl)-1 $\boldsymbol{H}$-indole (2). A solution of the compound 1 (140 mg. $0.7 \mathrm{mmol}$ ) and $\mathrm{Hg}(\mathrm{OAc})_{2}(27$ $\mathrm{mg}, 0.077 \mathrm{mmol})$ in acetic acid $(8 \mathrm{~mL})$ was heated at reflux for $3 \mathrm{~h}$. All volatiles were removed under reduced pressure, and to the residue was added an aqueous solution of saturated $\mathrm{K}_{2} \mathrm{CO}_{3}$. The mixture was extracted with $\mathrm{CH}_{2} \mathrm{Cl}_{2}$, and the organic layer was dried over $\mathrm{Na}_{2} \mathrm{SO}_{4}$, filtered, and concentrated under reduced pressure. The residue was purified by silica gel column chromatography $6 \%$ methanol in $\left.\mathrm{CH}_{2} \mathrm{Cl}_{2}\right)$ to yield the oxazole $2(75 \mathrm{mg}, 54 \%)$ : ${ }^{1} \mathrm{H}$ NMR (200 MHz, CDCl $): \delta 2.77(\mathrm{~s}, 3 \mathrm{H}), 6.22(\mathrm{~s}, 1 \mathrm{H}), 7.28-7.41$ $(\mathrm{m}, 2 \mathrm{H}), 7.53(\mathrm{~s}, 1 \mathrm{H}), 7.85(\mathrm{dd}, 1 \mathrm{H}, J=1.8,7.8 \mathrm{H} 7), 8.0(\mathrm{~d}$, $1 \mathrm{H}, J=8.3 \mathrm{~Hz}$ ), 9.9 (brs, $1 \mathrm{H}$ ).

Indoline-2-( $N$-2-hydroxyethyl)carboxamide (3). To a solution of indoline-2-carboxylic acid ethyl ester (191 mgn $1.0 \mathrm{mmol})$ in ethanol $(10 \mathrm{ml})$ was added 2-ethanolamine $(0.3 \mathrm{~mL}$, $6.0 \mathrm{mmol})$. The solution was heated at reflux for 4 $h$, and all volatiles were removed under reduced pressure. The residue was purified by silica gel column chromatography ( $10 \%$ methanol in $\left.\mathrm{CH}_{2} \mathrm{Cl}_{2}\right)$ to yield the compound 3 (189 mg. 92\%): 'H NMR (200 MHz. CDCl ): $\delta 3.02(\mathrm{~m}$. lH), 3.29-3.64 (m. 5H), 4.32 (dd. I H, $J=9.0,10.6 \mathrm{~Hz}), 6.69$ $(\mathrm{m}, 2 \mathrm{H}), 7.03(\mathrm{~m}, 2 \mathrm{H})$.

2-(1,3-Oxazolin-2-yl)-1 $\boldsymbol{H}$-indole (4). To a solution of the compound $3(50 \mathrm{mg}, 0.24 \mathrm{mmol})$, E $t_{3} \mathrm{~N}(0.12 \mathrm{~mL}, 1.0 \mathrm{mmol})$ and $\mathrm{CCl}_{4}(0.1 \mathrm{~mL}, 1.0 \mathrm{mmol})$ in $\mathrm{CH}_{3} \mathrm{CN}(5 \mathrm{~mL})$ was added a solution of triphenylphosphine in $\mathrm{CH}_{3} \mathrm{CN}(3 \mathrm{~mL})$ dropwise over $30 \mathrm{~min}$, and the reaction mixture was stirred for $3 \mathrm{~h}$ at room temperature, filtered off. The filtrate was concentrated under reduced pressure. The residue was purified by silica gel column chromatography $\left(5 \%\right.$ methanol in $\left.\mathrm{CH}_{2} \mathrm{Cl}_{2}\right)$ to yield the compound $4(28 \mathrm{mg}, 62 \%)$ : ${ }^{1} \mathrm{H}$ NMR (200 MHz. CDCl $): \delta 4.09(\mathrm{t}, 2 \mathrm{H}, J=9.4 \mathrm{~Hz}), 4.50(\mathrm{t}, 1 \mathrm{H}, J=9.4 \mathrm{~Hz})$, $7.05-7.40(\mathrm{~m}, 4 \mathrm{H}), 7.66(\mathrm{~d}, 1 \mathrm{H}, J=8.2 \mathrm{~Hz}), 9.94$ (brs, $\mathrm{lH}$ ).

I-(tert-Butoxycarbonyl)-indoline-2-carboxylic acid (5). To a solution of indoline-2-carboxylic acid $(5.0 \mathrm{~g}, 30.7$ mmol) and $\mathrm{Et}_{3} \mathrm{~N}(12.8 \mathrm{~mL}, 92 \mathrm{mmol})$ in $\mathrm{THF}^{\mathrm{TH}}(50 \mathrm{~mL})$ was added di-tert-butylcarbonate $(13.4 \mathrm{~g}, 61.4 \mathrm{mmol})$, and the 
reaction mixture was continuously stirred for $6 \mathrm{~h}$ at roon temperature. The suspension was concentrated under reduced pressure. and the residue was dissolved in an aqueous solution of $1 \mathrm{~N} \mathrm{NaOH}$, and washed with ether. The aqueous layer was acidified with conc. $\mathrm{HCl}$ until the solution becante cloudy, and was extracted with ethyl acetate. The organic layer was dried over $\mathrm{MgSO}_{4}$. filtered. and concentrated under reduced pressure. The residue was purified by silica gel column chromatography ( $10 \%$ methanol in $\mathrm{CH}_{2} \mathrm{Cl}_{2}$ ) to yield the compound 5 as an off white solid $(7.6 \mathrm{~g} .94 \%) ;{ }^{1} \mathrm{H}$ NMR (200 MHz, CD 3 OD): $\delta 1.27(\mathrm{~s} .9 \mathrm{H}), 3.1-3.6(\mathrm{~m} .2 \mathrm{H})$. $4.91(\mathrm{~m}, \mathrm{lH}) .6 .90-7.22$ (m. $3 \mathrm{H}), 7.80(\mathrm{~m}, \mathrm{lH})$.

1-(tert-Butoxycarbonyl)-indoline-2-( $N$-2-hydroxyethyl)carboxamide (6). To a solution of the compound 5 (1.0 g. 3.8 mimol) in $\mathrm{CH}_{2} \mathrm{Cl}_{2}(20 \mathrm{~mL})$ were added ethanolanine (0.46 mL. $7.6 \mathrm{~nm}$ ol). dicyclohexylcarbodiunide (862 $\mathrm{mg}$. $4.18 \mathrm{nmmol}$ ). and l-hydroxybenotriazole (564 $\mathrm{mg}, 4.19$ mmol). The reaction mixture was stirred overnight at roon temperature. and washed with an aqueous solution of $0.5 \mathrm{~N}$ $\mathrm{NaOH}$. The organic layer was dried over $\mathrm{MgSO}_{4}$. filtered. and concentrated under reduced pressure. The residue was purified by silica gel colunu chrontatography ( $10 \%$ methanol in $\left.\mathrm{CH}_{2} \mathrm{Cl}_{2}\right)$ to yield the compound $6(1.12 \mathrm{~g}, 97 \%)$ : ${ }^{1} \mathrm{H}$ NMR $\left(200 \mathrm{MHz}_{2} \mathrm{CDCl}_{\mathrm{j}}\right.$ ): $\delta \mathrm{l} .40$ (d, IH. $\left.J=6.0 \mathrm{~Hz}\right) .3 .42$ (s. $3 \mathrm{H}$ ). $3.49(\mathrm{~s}, 3 \mathrm{H}), 4.35-4.44(\mathrm{~m}, 3 \mathrm{H}) .4 .57$ (m. lH) 7.04 (d, lH, $J$ $=8.0 \mathrm{~Hz}) .8 \cdot 10-8.24(\mathrm{ml} .2 \mathrm{H}): \mathrm{MS} 306\left[\mathrm{M}^{-}\right]$.

1-(tert-Butoxycarbonyl)-2-(oxazolin-2-yl)-indoline (7). To a solution of the anide $6(90 \mathrm{~m} g .0 .29 \mathrm{nmmol})$ in $\mathrm{CH}_{2} \mathrm{Cl}_{2}$ $(2 \mathrm{~mL})$ were added diethylaminosulfur trifluoride $(42 \mu \mathrm{L}$. $0.32 \mathrm{mmol}$ ) and $\mathrm{K}_{2} \mathrm{CO}_{3}(80 \mathrm{mg}, 0.58 \mathrm{mmol})$ at $-78^{\circ} \mathrm{C}$. The reaction misture was warmed to room temperature and stirred for $4 \mathrm{~h}$, then washed with water. The organic layer was dried over $\mathrm{Na}_{2} \mathrm{SO}_{4}$, filtered. and concentrated under reduced pressure. The residue was purified by silica gel columin chromatography ( $5 \%$ methanol in dichloromethane) to yield the compound 7 (77 $\mathrm{mg}, 91 \%)$ : ${ }^{1} \mathrm{H} \mathrm{NMR} \mathrm{(200} \mathrm{MHz.}$ $\left.\mathrm{CDCl}_{3}\right): \delta 1.52(\mathrm{~s} .9 \mathrm{H}), 3.14(\mathrm{dd}, 1 \mathrm{H}, J=4.2 .14 .0 \mathrm{~Hz}), 3.48$ (dd, IH. $J=10.6,14.1 \mathrm{~Hz}), 3.82(\mathrm{~m}, 2 \mathrm{H}) .4 .23(\mathrm{~m}, 2 \mathrm{H}) .5 .10$ (m. $1 \mathrm{H}), 6.93(1 \mathrm{H}, \mathrm{dd}, J=7.3,7.5 \mathrm{~Hz}) .7 .14$ (m. $2 \mathrm{H}$ ), 7.8 (br. lH): MS $288\left[\mathrm{M}^{+}\right]$.

1-(tert-Butoxycarbonyl)-indoline-2-carboxyhydrazide (8). Ethyl 1-(tert-butyloxycarbonyl)indoline-2-carboxylate (1.0 g. $3.0 \mathrm{~mm}$ ol) was dissolved in methanol $(10 \mathrm{~mL})$ and hydrazine hydrate $(1.5 \mathrm{~mL})$, and the solution was heated at reflux for $20 \mathrm{~h}$. An acidic solution was washed with $\mathrm{CH}_{2} \mathrm{Cl}_{3}$ $(10 \mathrm{~mL})$. and basified with an aqueous solution of $2 \mathrm{~N}$ $\mathrm{NaOH}$ to $\mathrm{pH} 8-9$, then extracted with etlyl acetate $(15 \mathrm{~mL} \times$ 2). Evaporation of the solvents yielded the hydrazide 8 (920 mg, $96 \%$ ). which was used without further purification: ${ }^{l} \mathrm{H}$ NMR (200 MHz. CDCl $/$ DMSO): $\delta 1.53$ (s, 9H), 3.09 (dd. $1 \mathrm{H}, J=4.9 .14 .7 \mathrm{~Hz}$ ). 3.44 (dd. IH. $J=11.0 .15 .5 \mathrm{~Hz}), 4.78$ (dd, $1 \mathrm{H}, J=5.1 .11 .0 \mathrm{~Hz}$ ). 6.92 (dd, $1 \mathrm{H} . J=7.3,7.5 \mathrm{~Hz}$ ). 7.12 (d, 2H), 7.65 (br. $1 \mathrm{H}), 8.9 \mathrm{l}$ (br, $\mathrm{lH}$ ).

1-(tert-Butoxycarbonyl)-2-(5-methyl-1,3,4-oxadiazol-2yl)-indoline (9). A solution of the hydrazide $9(300 \mathrm{mg} .1 .08$ mmol) and trietlyl orthoacetate $(1.4 \mathrm{~mL} .10 .8 \mathrm{mmol})$ in methanol (5 mL) was heated at reflux for $9 \mathrm{~h}$ and cooled. then concentrated under reduced pressure. The residue was dissolved in tent-butanol $(5 \mathrm{~mL})$, and potassium tentbutoxide ( $180 \mathrm{mg}, 1.6 \mathrm{~mm}$ ol) was added to it. The reaction mixture was heated at reflux for $11 \mathrm{~h}$, and concentrated under reduced pressure. The residue was partitioned between $\mathrm{CH}_{2} \mathrm{Cl}_{2}$ and an aqueous solution of $2 \mathrm{M} \mathrm{K}_{2} \mathrm{CO}_{2}$. The organic layer was dried over $\mathrm{Na}_{2} \mathrm{SO}_{4}$. filtered, and concentrated under reduced pressure. The residue was purified by silica gel column cluromatography ( $n$-hexane : ethyl acetate $=1: 1)$ to afford the oxadiazole $9(100 \mathrm{mg}, 31 \%):{ }^{1} \mathrm{H}$ NMR $\left(200 \mathrm{MHz}_{2} \mathrm{CDCl}_{3}\right): \delta 1.48(\mathrm{~s}, 9 \mathrm{H}) .2 .49(\mathrm{~s}, 3 \mathrm{H}) .3 .28$ (dd, $1 \mathrm{H}, J=3.9,16.5 \mathrm{~Hz}) .3 .65$ (dd, $1 \mathrm{H} . J=10.7,16.5 \mathrm{~Hz}$ ), 5.68 (dd. $1 \mathrm{H}, J=4.0 .10 .6 \mathrm{~Hz}$ ). 6.99 (dd. IH. $J=7.3,7.4$

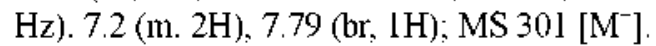

1-(tert-Butoxycarbonyl)-indoline-2-carboxamide (10). To a solution of the acid $5(2.63 \mathrm{~g}, 10 \mathrm{mmol})$ and $\mathrm{Et}_{3} \mathrm{~N}(2.8$ $\mathrm{mL}, 20 \mathrm{~nm}$ ol) in THF (100 $\mathrm{mL})$ was added ethyl chloroformate $(1.3 \mathrm{~mL} .12 \mathrm{mmol})$ dropwise at $0^{\circ} \mathrm{C}$. and it was stirred for $30 \mathrm{~min}$. Gaseous $\mathrm{NH}_{3}$ was bobbled into the solution for $30 \mathrm{~min}$, and the reaction misture was continuously stirred for $2 \mathrm{~h}$ at room temperature. Water was added to the mixture, which was extracted with ethyl acetate. The organic layer was washed with brine and water. dried over $\mathrm{MgSO}_{4}$. filtered. and concentrated under reduced pressure. The residue was purified by silica gel column chromatography ( $n$-hexane : ethyl acetate $=1: 1$ ) to yield the compound $10(2.5 \mathrm{~g}, 95 \%)$ as an off white solid; ${ }^{1} \mathrm{H}$ NMR $\left(200 \mathrm{MHz}, \mathrm{CDCl}_{3}\right): \delta 1.53$ (s, 9H). 3.08 (dd. $1 \mathrm{H}, J=4.3$, $16.3 \mathrm{~Hz}$ ). 3.52 (dd, lH, $J=11.4 .16 .3 \mathrm{~Hz}), 4.82(\mathrm{~m}, \mathrm{lH})$, 6.88 (dd. IH. $J=7.0 .7 .3 \mathrm{~Hz}), 7.14(\mathrm{~m}, 2 \mathrm{H}), 7.84$ (br. $\mathrm{lH}$ ); MS $262\left[\mathrm{M}^{+}\right]$

1-(tert-Butoxycarbonyl)-2-(1,2,4-oxadiazol-5-yl)-indoline (11). A solution of the amide $10(1.0 \mathrm{~g} .3 .8 \mathrm{mmol})$ in dimetlylformamide dimetlyacetal $(4 \mathrm{~mL})$ was heated at reflux for $3 \mathrm{~h}$, and was concentrated under reduced pressure. To the residue an $1 \mathrm{M}$ solution of hydroxylamine hydrocluloride in $1 \mathrm{~N} \mathrm{NaOH}$ (742 $\mathrm{mg}, 10.5 \mathrm{~mL}$ ). dioxane (10.5 $\mathrm{mL})$, and acetic acid $(14 \mathrm{~mL})$ were added. The resulting mixture was heated at reflux for $4 \mathrm{lh}$. and all volatiles were removed under reduced pressure. To the residue an aqueous solution of saturated $\mathrm{NaHCO}_{3}$ was added, and it was extracted with $\mathrm{CH}_{2} \mathrm{Cl}_{2}$. The organic layer was washed with an aqueous solution of saturated $\mathrm{NaHCO}_{3}$ and water, dried over $\mathrm{Na}_{2} \mathrm{SO}_{4}$. filtered. and concentrated under reduced pressure. The residue was purified by silica gel column cluromatography (hexane : ethyl acetate $=4: 1$ ) to give an off white solid ( $510 \mathrm{mg}, 47 \%$ ): ${ }^{l} \mathrm{H}$ NMR (200 MHz, CDCl 3$)$ : $\delta 3.21$ (dd. $1 \mathrm{H}, J=3.9 .16 .5 \mathrm{~Hz}$ ). 3.79 (dd. $1 \mathrm{H}, J=11.0,16.6$ Hz). 5.72 (dd, $1 \mathrm{H}, J=3.7 .10 .8 \mathrm{~Hz}$ ), 7.03 (dd. $1 \mathrm{H}, J=7.3$, $7.4 \mathrm{~Hz}$ ). 7.13-7.28 (m, 2H), 7.91 (br. $1 \mathrm{H}), 8.37$ (s. 1H).

1-(tert-Butoxycarbonyl)-indoline-2-carbonitıile (12). To a solution of the amide $10(4.0 \mathrm{~g} .15 .2 \mathrm{mmol})$ and DMSO (2.16 mL. $25.9 \mathrm{mmol})$ in $\mathrm{CH}_{2} \mathrm{Cl}_{2}(40 \mathrm{~mL})$ was added a solution of oxalyl chloride ( $1.73 \mathrm{~mL}, 19.8 \mathrm{mmol}$ ) in $\mathrm{CH}_{2} \mathrm{Cl}_{2}$ $\left(10 \mathrm{~mL}\right.$ ) dropwise at $.78^{\circ} \mathrm{C}$. After stirring for $15 \mathrm{~min}$ at -78 ${ }^{\circ} \mathrm{C}, \mathrm{Et}_{2} \mathrm{~N}(1.73 \mathrm{~mL} .19 .8 \mathrm{mmol})$ was added dropwise to the mixture. and it was stirred for $1 \mathrm{~h}$ at $-78^{\circ} \mathrm{C}$. The reaction 
mixture was quenched with water $(50 \mathrm{~mL})$, warmed to room temperature. and extracted with ethyl acetate. The organic layer was washed with brine, dried over $\mathrm{Na}_{2} \mathrm{SO}_{4}$. filtered. and concentrated under reduced pressure. The residue was purified by silica gel column chromatography (n-hexane ethyl acetate $=4: 1)$ to give the nitrile $12(2.38 \mathrm{~g} .64 \%)$ as a white solid: ${ }^{1} \mathrm{H}$ NMR (200 MHz. $\left.\mathrm{CDCl}_{3}\right): \delta 1.61(\mathrm{~s}, 9 \mathrm{H})$. 3.27-3.68 (m. $2 \mathrm{H}$ ). 5.08 (br, $1 \mathrm{H}$ ). 7.06 (dd. $1 \mathrm{H}, J=7.5 .8 .0$ Hz). $7.20(\mathrm{ml} .2 \mathrm{H}), 7.79(\mathrm{br}, \mathrm{lH})$; $\mathrm{MS} 244\left[\mathrm{M}^{-}\right]$.

1-(tert-Butoxycarbonyl)-2-(5-methyl-1,2,4-0xadiazol-3yl)-indoline (13). The nitrile 12 ( $1.0 \mathrm{~g}$. $4.08 \mathrm{~mm}$ mol). hydrosylamine hydrochloride ( $848 \mathrm{mg} .12 .24 \mathrm{mmol})$. and $\mathrm{K}_{3} \mathrm{CO}_{3}(1.04 \mathrm{~g}, 8.16 \mathrm{mmol})$ were added to boiling ethanol $(15 \mathrm{~mL})$, and it was heated at reflux for $12 \mathrm{~h}$. After evaporation of ethanol, the residue was dried over $\mathrm{P}_{2} \mathrm{O}_{\Sigma}$ in high vacuum. and was treated with acetic anhydride $(15 \mathrm{~mL})$ at $0^{\circ} \mathrm{C}$. The mixture was heated at reflux for $2 \mathrm{~h}$, and excess acetic anhydride was removed under reduced pressure. The residue was treated with an aqueous solution of saturated $\mathrm{K}_{3} \mathrm{CO}_{3}$. then extracted with $\mathrm{CH}_{3} \mathrm{Cl}_{3}$. The organic layer was dried over $\mathrm{Na}_{3} \mathrm{SO}_{4}$. filtered. and concentrated under reduced pressure. The residue was purified by silica gel column chromatography to give the compound $13(280 \mathrm{mg} .22 \%$ ): ${ }^{1} \mathrm{H}$ NMR $\left(200 \mathrm{MHz}, \mathrm{CDCl}_{3}\right): \delta 1.57(\mathrm{~s}, 9 \mathrm{H}), 2.42(\mathrm{~s}, 3 \mathrm{H})$. $3.2-3.6(\mathrm{~m}, 2 \mathrm{H}) .5 .02(\mathrm{~m} . \mathrm{lH}) .7 .04(\mathrm{dd}, \mathrm{lH} . J=7.3,7.3 \mathrm{~Hz})$. $7.20(\mathrm{ml}, 2 \mathrm{H}) .7 .4 \mathrm{l}$ (br. $1 \mathrm{H})$.

1-(tert-Butoxycarbonyl)-2-(terazol-5-yl)-indoline (14). To a solution of the nitrile compound 12 (600 mg. 2.46 $\mathrm{mmol})$ in toluene $(50 \mathrm{~mL})$ were added $\mathrm{NaN}_{\hat{3}}(1.28 \mathrm{~g}, 19.7$ $\mathrm{mmol})$ and triethy lanine hydrochloride $(2.7 \mathrm{lg} .19 .7 \mathrm{mmol})$ and the reaction mixture was stirred at $80^{\circ} \mathrm{C}$ for $3 \mathrm{~h}$. To the mixture water was added and the layers were separated. The aqueous layer was extracted with ether. The combined organic layers were dried over $\mathrm{Na}_{-} \mathrm{SO}_{4}$, filtered. and concentrated under reduced pressure. The residue was purified by silica gel colunu chromatography ( $10 \%$ methanol in $\mathrm{CH}_{2} \mathrm{Cl}_{2}$ ) to give an off white solid $(640 \mathrm{mg}, 91 \%)$ : ${ }^{1} \mathrm{H}$ NMR (200 $\mathrm{MHz} . \mathrm{CDCl}_{3}$ ): $\delta \mathrm{l} .38(\mathrm{~s}, 9 \mathrm{H}) .3 .09$ (m. $\left.\mathrm{lH}\right), 3.76$ (dd, $1 \mathrm{H} . J$ $=11.0,16.9 \mathrm{~Hz}) .5 .85(\mathrm{dd}, 1 \mathrm{H}, J=4.5 .11 .0 \mathrm{~Hz}), 7.00(\mathrm{dd}$. $1 \mathrm{H}, J=7.0 .7 .9 \mathrm{~Hz}), 7.22(\mathrm{~m} .2 \mathrm{H}) .7 .78(\mathrm{br}, \mathrm{lH})$

1-(tert-Butoxycarbonyl)-2-(1-methylterazol-5-yl)-indoline (15). To a solution of the compound $14(450 \mathrm{mg} .1 .57 \mathrm{mmol})$ in DMF were added $\mathrm{K}_{3} \mathrm{CO}_{3}(420 \mathrm{mg} .3 \mathrm{mmol})$ and $\mathrm{CH}_{3} \mathrm{I}$ $(180 \mathrm{~mL}, 3 \mathrm{mmol})$. and the reaction mixture was stirred at room temperature for $5 \mathrm{~h}$. To the mixture water was added and the aqueous layer was extracted with $\mathrm{CH}_{2} \mathrm{Cl}_{3}$. The organic layer was dried over $\mathrm{Na}_{2} \mathrm{SO}_{4}$. filtered. and concentrated under reduced pressure. The residue was separated by silica gel column chromatography (hexane : ethyl acetate = $3: 1)$ to give the regioisoners. 1-methyltetrazole compound (15. $220 \mathrm{mg} .46 \% . \mathrm{R}_{f}=0.24$ in hexane : ethyl acetate $=$ $2: 1$ ), and 2-methyltetrazole compound (16. $240 \mathrm{mg} .51 \%$. $\mathrm{R}_{f}=0.29$ in hexane : ethyl acetate $\left.=2: 1\right):{ }^{l} \mathrm{H}$ NMR $(200$ $\mathrm{MHz} . \mathrm{CDCl}_{3}$ ): $\delta 1.42(\mathrm{~s}, 9 \mathrm{H}) .3 .21(\mathrm{~m} . \mathrm{HH}), 3.76$ (dd, $1 \mathrm{H} . J$ $=11.6 .15 .9 \mathrm{~Hz}), 4.0(\mathrm{brs}, 3 \mathrm{H}) .4 .59(\mathrm{~m}, \mathrm{lH}) .5 .81(\mathrm{~m}, \mathrm{lH})$. 7.07 (dd. IH. $J=7.1,7.1 \mathrm{~Hz}), 7.2(\mathrm{~m} .2 \mathrm{H}), 7.65(\mathrm{brs}, \mathrm{lH})$.

1-(tert-Butoxycarbonyl)-2-(2-methylterazol-5-yl)-indoline
(16). ${ }^{1} \mathrm{H}$ NMR $\left(200 \mathrm{MHz}, \mathrm{CDCl}_{3}\right): \delta 1.44$ (s. $\left.9 \mathrm{H}\right), 3.19$ (dd, IH. $J=3.3,16.3 \mathrm{~Hz}$ ). 3.68 (dd. $1 \mathrm{H}, \mathrm{J}=10.4 .16 .1 \mathrm{~Hz}), 4.27$ $(\mathrm{s}, 3 \mathrm{H}) .5 .78$ (dd, IH. $J=3.2 .10 .4 \mathrm{~Hz}) .6 .98(\mathrm{dd}, \mathrm{lH} . J=$ $7.3,7.5 \mathrm{~Hz}$ ). $7.23(\mathrm{~m}, 2 \mathrm{H}) .7 .80$ (brs. $1 \mathrm{H}$ ).

2-(1-Methylterazol-5-yl)-indoline (17). A solution of the compound 15 (200 mg. $0.66 \mathrm{mmol}$ ) in $\mathrm{CH}_{2} \mathrm{Cl}_{2}(2 \mathrm{~mL}$ ) and trifluoroacetic acid $(2 \mathrm{~mL})$ was stirred for $4 \mathrm{~h}$ at room temperature, and the solvent was evaporated under reduced pressure. To the residue an aqueous solution of saturated $\mathrm{NaHCO}_{3}$ was added carefully, which was extracted with $\mathrm{CH}_{2} \mathrm{Cl}_{2}$. The organic layer was carefully washed with an aqueous solution of saturated $\mathrm{NaHCO}_{3}$ and water. dried over $\mathrm{Na}_{2} \mathrm{SO}_{4}$. filtered, concentrated under reduced pressure. The residue was purified by silica gel column chromatography (n-hexane : ethyl acetate $=1: 1$ ) to yield an off white solid 17 (82 mg. 61\%): ${ }^{1} \mathrm{H}$ NMR (200 MHz, $\mathrm{CDCl}_{3}$ ): $\delta 3.17$ (dd, 1H. $J=9.4,15.8 \mathrm{~Hz}) .3 .63$ (dd, $1 \mathrm{H}, J=10.2 .15 .8 \mathrm{~Hz}), 4.11$ $(\mathrm{s}, 3 \mathrm{H}), 5.52$ (dd. $1 \mathrm{H} . J=9.7 .10 .3 \mathrm{~Hz}) .6 .8(\mathrm{~m} .2 \mathrm{H}), 7.1(\mathrm{~m}$, $2 \mathrm{H})$.

2-(2-Methylterazol-5-yl)-indoline (18). Using the compound 16 (200 $\mathrm{mg} .0 .66 \mathrm{mmol}$ ) the same reaction as the preparation of the compound $\mathbf{1 7}$ was proceeded to give an off white solid ( $83 \mathrm{mg} .62 \%$ ): ${ }^{1} \mathrm{H}$ NMR (200 MHz, $\mathrm{CDCl}_{3}$ ): $\delta 3.5(\mathrm{~m} .2 \mathrm{H}) .3 .63$ (dd. $1 \mathrm{H} . J=10.2,15.8 \mathrm{~Hz}), 4.11$ (s. $3 \mathrm{H})$, 5.19 (dd. $1 \mathrm{H}, J=7.3 .8 .7 \mathrm{~Hz}$ ). $6.75(\mathrm{~m} .2 \mathrm{H}), 7.08(\mathrm{~m} .2 \mathrm{H}$ ).

1-[(2S,3R,4S)-3,4-Dihydro-2-dimethoxymethyl-3-hydroxy-2-methyl-6-nitro-2H-1-benzopyran-4-yl]-2-(2R)-(1methyltetrazol-5-yl)-indoline (19). The reaction misture of tetrazole indoline 17 (150 $\mathrm{mg} .0 .75 \mathrm{mmol})$, optically pure (2S. $3 R .4 R$ ) epoxide ( $210 \mathrm{mg} .0 .75 \mathrm{mmol})$, and $\mathrm{Mg}\left(\mathrm{ClO}_{4}\right)$, (167 mg. $0.75 \mathrm{mmol}$ ) in $\mathrm{CH}_{3} \mathrm{CN}(0.8 \mathrm{~mL}$ ) was stirred at room temperature for $6 \mathrm{~h}$. and it was concentrated under reduced pressure. Resulting two diastereomers were separated by silica gel column chromatograply (hexane : etlyl acetate $=2: 1$ ). and the isomer (19) with $2 R$ at indoline ring, faster moving one. was obtained as a pale yellow foam $(62 \mathrm{mg}$. 17\%): ${ }^{1} \mathrm{H}$ NMR (200 MHz. $\mathrm{CDCl}_{3}$ ): $\delta$ 1.55 (s. 3H). 3.2-3.5 (m. $8 \mathrm{H}$ ). $4.1 \mathrm{l}$ (s. $3 \mathrm{H}$ ). $4.3-4.5$ (m. $2 \mathrm{H}$ ). 5.5-5.8 (m. 2H). 6.6$7.0(\mathrm{~m} .3 \mathrm{H}), 7.18(\mathrm{~m} .2 \mathrm{H}), 7.8-8.1(\mathrm{~m} .2 \mathrm{H})$.

$1-[(2 S, 3 R,+S)-3,+-D i h y d r 0-2-$ dimethoxymethyl-3-hydroxy-2-methyl-6-nitro-2 $H$-1-benzopyran-4-yl]-2-(2S)-(1methyltetrazol-5-yl)-indoline (20). From the reaction to prepare the compound 19. the isomer (20) with $2 S$ at indoline ring, slower moving one, was obtained as a pale yellow foam (48 mg. $13 \%$ ): ' $\mathrm{H}$ NMR ( $200 \mathrm{MHz}, \mathrm{CDCl}_{3}$ ): $\delta$ $1.57(\mathrm{~s} .3 \mathrm{H}) .3 .2-3.8(\mathrm{~m} .7 \mathrm{H}), 3.9-4.1(\mathrm{~m}, 2 \mathrm{H}) .4 .28(\mathrm{~s} .3 \mathrm{H})$, $4.3-4.5(\mathrm{~m} .2 \mathrm{H}) .5 .63(\mathrm{~m} . \mathrm{lH}) .6 .2 \mathrm{l}(\mathrm{m} . \mathrm{lH}) .6 .7-7.0(\mathrm{~m}$. $3 \mathrm{H}) .7 .16(\mathrm{~m}, \mathrm{lH}) .7 .8-8.2(\mathrm{~m}, 2 \mathrm{H})$.

1-[(2S,3R,4S)-3,4-Dihydro-2-dimethoxymethyl-3-hydroxy-2-methyl-6-nitro-2H-1-benzopyran-t-yl]-2-(2R)-(2methyltetrazol-5-yl)-indoline (21). The same reaction for the preparation of the compound 19 was proceeded except using the tetrazole indoline $\mathbf{1 8}(150 \mathrm{mg}, 0.75 \mathrm{mmol}$ ) as a starting material. The isomer (21) with $2 R$ at indoline ring. faster moving one. was obtained as a pale yellow foam ( 160 mg. $45 \%$ ): ${ }^{l} \mathrm{H} \mathrm{NMR}\left(200 \mathrm{MHz}, \mathrm{CDCl}_{3}\right): \delta 1.67(\mathrm{~s}, 3 \mathrm{H}) .3 .4 \mathrm{l}$ $(\mathrm{s}, 3 \mathrm{H}), 3.48$ (s. $3 \mathrm{H}) .3 .61$ (m, 2H), 3.99 (s. $3 \mathrm{H}) .4 .19$ (m, 
1H), 4.32 (n. $1 \mathrm{H}), 5.13$ (d, lH), 5.38 (m. IH), 6.5-6.9 (m. $3 \mathrm{H}), 7.18(\mathrm{~m} .2 \mathrm{H}), 7.8-8.0(\mathrm{~m} .2 \mathrm{H})$.

1-[(2S,3R,4S)-3,4-Dihydro-2-dimethoxymethyl-3-hydroxy-2-methyl-6-nitro- $2 H$-1-benzopyran-4-y])-2-(2S)-(2methyltetrazol-5-yl)-indoline (22). From the reaction to prepare the compound $\mathbf{2 1}$, the isomer (22) with $2 S$ at indoline ring, slower moving one. was obtained as a pale yellow foan ( $170 \mathrm{mg} .47 \%$ ): ${ }^{1} \mathrm{H}$ NMR $\left(200 \mathrm{MHz} . \mathrm{CDCl}_{3}\right): \delta$ 1.57 (s. $3 \mathrm{H}), 3.40$ (s. $3 \mathrm{H}), 3.46(\mathrm{~s}, 3 \mathrm{H}) .3 .5-3.7(\mathrm{~m}, 2 \mathrm{H}), 4.2 \mathrm{I}$ (m. $\mathrm{lH}), 4.42(\mathrm{~s}, 3 \mathrm{H}), 4.5-4.7$ (n. $2 \mathrm{H}), 5.30(\mathrm{~m}, \mathrm{lH}), 5.82$ (m. $\mathrm{lH}), 6.7$ (n. $2 \mathrm{H}), 6.90$ (d. $1 \mathrm{H}, J=9.0 \mathrm{~Hz}) .7 .12(\mathrm{~m}, \mathrm{lH})$. 8.02 (dd. $1 \mathrm{H} . J=2.8,7.8 \mathrm{~Hz}$ ), 8.41 (brs, $\mathrm{lH}$ ).

1-[(2S,3R,4S)-3,4-Dihydro-2-dimethoxymethy]-3-hydroxy-2-methyl-6-nitro-2H-1-benzopyran-4-yl)-2-(2-methyltetrazol-5-yl)-1 $H$-indole (23). To a solution of indoline conpounds (21, 22. $50 \mathrm{mg}, 0.104 \mathrm{mmol})$ in benzene $(4 \mathrm{~mL})$ was added DDQ (47 $\mathrm{mg}, 0.21 \mathrm{mmol})$ and the reaction mixture was stirred at room temperature for $6 \mathrm{~h}$. The reaction mixture was diluted with ethyl acetate $(4 \mathrm{~mL})$ and washed with $10 \% \mathrm{NaOH}$ and water. The organic layer was dried over $\mathrm{Na}_{-} \mathrm{SO}_{4}$. filtered. and concentrated under reduced pressure. The residue was purified with silica gel colunn cluromatography (hexane : ethyl acetate $=1: 1$ ) to give the pale yellow foam $(45.3 \mathrm{mg} .91 \%)$. ${ }^{1} \mathrm{H}$ NMR $(200 \mathrm{MHz}$. $\left.\mathrm{CDCl}_{3}\right): \delta 1.65(\mathrm{~s}, 3 \mathrm{H}) .3 .52$ (s. $\left.3 \mathrm{H}\right), 3.54$ (s. $\left.3 \mathrm{H}\right), 3.68$ (d. $1 \mathrm{H}, J=10.2 \mathrm{~Hz}), 4.45$ (s. $3 \mathrm{H}), 4.48$ (d. $1 \mathrm{H}, J=10.3 \mathrm{~Hz}$ ). 4.67 (s. $1 \mathrm{H}) .6 .50$ (d, IH. $J=8.1 \mathrm{~Hz}), 6.9-7.2$ (m. $3 \mathrm{H}) .7 .35$ (s. $1 \mathrm{H}), 7.72(\mathrm{~m}, 2 \mathrm{H}) .8 .12$ (dd. $1 \mathrm{H} . J=1.8,8.9 \mathrm{~Hz}$ ).

\section{References}

1. Lee. S.: Y. K.Y.: Kim. S.-K.: Suh. J.: Kim. N. T.: Yoo. S.-e.: Lee. B. H.: Seo. H. W.: Kim. S.-O.: Lim. H. Europ. J. Hed. Chem. 2003. 38,459

2. Yoo. S.e: Y, K. Y.: Lee, S: Suh, J.; Kim, N.; Lee. B. H.: Seo. H. W. Kim, S.-O.; Lee, D.-H. Lim, H.: Shin. H. S. J. Med Chent 2001. H. 4207.

3. Street. L. J.: Baker. R.: Castro. J. L.: Chambers. M. S.: Guiblin. A. R.: Hobbs. S. C.: Matassa. V. G.: Reeve. A. J.: Beer. M. S.: Middlemiss. D. N.; Noble, A. J.: Stanton. J. A: Scholey. K. Hargreves, R. J. J. hed Chent. 1993,36. 1529 .

4. Vorbruggen. $\mathrm{H} ;$ Krolikiewicz, K. Tetrahedhon 1993. 19,9353

5. Collot. V.: Schmitt. M: Marwah. A. K.: Norberg. B.: Bourguignton. J.-T. Tetrahedron Lett 1997.38.8033.

6. (a) Phillips. A. T.: Uto. Y.: Wipf. P.: Reno. M. J.: Wilians. D. R. Org. Lett 2000, 2, 1165 . (b) Jones, G.: Butler, D. C.: Richards. C. J. Tetrahe don Lett. 2000. 1.9351

7. Orlek. B. S.: Blaney, F. E.; Brown. F.; Clark. M. S. G.: Hadley, M. S.: Hatcher. T.: Riley. G. J.: Rosenberg. H. E.: Wadsworth. H. T.: Wyman. P. J. Hed Chem 1991. 34.2726.

8. Lin. Y.: Lang. S. A.: Lovell. M. F.: Perkinson. N. A. J. Org. Chem. 1979. $H, 4160$.

9. Saunders. J.: Cassidy, M.; Freedman, S. B.; Harley. E. A.; Iversen. L. L.; Kneen, C.: MacLead, A. M.; Merchant. K. J.: Snow, R. J.; Baker. R. J. Mled. Chem 1990. 33. 1128.

10. Omura. K.: Swem. D. Tetrahedron Lett 1978. 34. 1651.

11. Ubukata. M.: Sonoda. T.: Isono. K. Natwal Product Letters 1992. 1. 149

12. Nakajima. N.: Ubukata, M. Tetrahedron Lett. 1997, 38, 2099.

13. Finnegan. W. G.; Henry, R. A.; Lofquist. R. J. Ant Chent Soc. 1958. 80.3908

14. Chini. M.: Crotti. P.: Macchia. F. Tetrahedron Lett 1990. 31.4661. 